DOI https://doi.org/10.30525/978-9934-588-91-4-40

\title{
PUBLIC ORGANIZATIONS IN THE FRAMEWORK OF EUROPEAN STANDARDS: PROSPECTS AND DILEMMAS OF ACCOMMODATION OF UKRAINIAN LEGISLATION
}

\author{
Tikhonova O. V. \\ Postgraduate student at the Department of Political Sciences \\ M. P. Dragomanov National Pedagogical University \\ Kyiv, Ukraine
}

Public organizations and associations always symbolize democracy, humanism, legality and the rule of law. With the help of public (or people's) initiative, society fulfils and implements the function of self-representation which, in fact, is a symbol of socialization of the state and its application of «soft law» in relation to its own citizens.

American researcher, scientist and political scientist John Wright notes the following trend: in the European Union, the support from the government and governmental administrative apparatus is received only by those public organizations that can clearly and consistently outline a vision for the future development of loyal civil society - and, consequently, appropriate trends to person-centered changes in it.

As you know, the EU Biennial Project for 2017-2019 was relatively recently developed and put into effect. Accordingly, this act regulates and approves the obligation to promote and cultivate democracy and theories of civil society in Ukraine. It should be noted that, in fact, this is a process of accommodation (i.e. adaptation) of the Ukrainian state and legislative field of public activity management and its simultaneous harmonization with the standards of the European Union [1].

The Association Agreement between Ukraine and the EU dated 2014 is the guiding and fundamental in the context of humane state-building and the process of following the Euro-Atlantic governmental course for Ukraine. It should be noted that some European integration transformations and features related to the style of governmental administration in the European Union and the state of Ukraine are conceptually similar: both EU member states and Ukraine belong to the Romano-Germanic legal family. Such a conclusion, in turn, leads to a conclusion about the positive prospects for the implementation of pro-European political trends and views in the structure of the state and social apparatus in general [2].

Foreign experience shows that: public organizations are most often associated with non-profit and non-government concepts. There is also an unspoken division - for example, in the United States of America, a public 
organization is often associated with an inability to make a profit; at the same time, in the member states of the European Union the association of social activity with the «non-government nature of the organization» is most common. Thus, based on the stylistic and conceptual views expressed by the UN and reflected in its own Charter dated 1945, the Euro-Atlantic view of the essence of public organizations can be defined as an ideologically inspired, self-implemented path of civil society to improve its own conditions of existence. In fact, the position given by the European Union states that: the status of a public association and its success is decided not only by the state itself; it is a process of self-consciousness of the society, its political and social activity: the main attribute - is patriotism and the desire for a constructive dialogue with the authorities and institutions. Moreover, the experience of the United States of America, which can rightly be considered as «cradle of democracy», leads to the following conclusion: humanism as a state course and the existence of political and social dialogue between the state and civil society is a mutual, bilateral process involving two equal players [3].

Historically and retrospectively, the situation with the formation of public associations in the European Union had a complex structure. For example, in the Middle Ages (and before) the conditional division into groups was common: depending on the level of ability of social groups to address issues of social and political nature. Eventually, this picture underwent transformational changes, as the trend towards democracy in Europe began to gain momentum. This was reflected, first of all, in the permission to establish political parties, public organizations and trade unions, and, as a result - in the consolidation of similar regulations in the national legislation of the member states of the European Union. It is worth noting that the driving force and the way of moving towards the humanization of society were originally Ancient Rome and Ancient Greece. As you know, civil society can only be built through hard work. Losses - both human and political and social, more clearly define and outline the importance of the democratic movement in any state, which are focused on ensuring the rights, freedoms and interests of citizens and the society [4].

In Ukraine, the situation with the legislative regulation of the activity of public organizations is in a rather static situation. There is the Law of Ukraine «On Public Associations», which regulates the activity of public and other non-governmental organizations. At the same time, this Law necessarily identifies the concept of public association with the protection and improvement of cultural, social, economic and public interest. This approach is quite progressive, as it allows to focus on the values inherent in Western European political and legal culture: in fact, the creation of public organizations, their non-profit and non-government nature serve to ensure the 
functioning of a crucial component of civil society - democratism in the context of attitude to human as the highest social value (which, in fact, is specified in the Fundamental Law - the Constitution of Ukraine) [5].

Legislative regulation of the freedom to form a public association should be clearly regulated. The reflection in the Fundamental Law (Constitution) of the right to freedom of association - is a manifestation of the social direction of the state and the government and power apparatus of the state and the focus on social dialogue with citizens in the legal field. Prominent examples are Austria (Articles 12, 27 of the Constitution) and Denmark (Articles 78-79 of the Constitution), where, given the legitimacy of the purpose and the legitimate desire to create a public association, citizens have the right to immediately implement the above constitutional guarantee). In Ukraine, the right for association of citizens is declared by the Fundamental Law - the Constitution of Ukraine (Article 36). Accordingly, theoretical and practical aspects of governmental administration in Ukraine and in the developed countries of the European Union have common features: the approach used in Ukraine has a number of Euro-oriented features and characteristics. Another such sign - is the voluntary entry into a public organization or the inadmissibility of a forced ban on participation in it. The abovementioned constitutional guarantee is especially important, as it provides a declaration of the absolute and inviolable right of the citizen to imitativeness and the rule of people, which, in turn, is guaranteed by the Constitution of Ukraine. In 2002, in Strasbourg, the Council of Europe adopted the «Fundamental Principles on the Status of Non-governmental organizations», which clearly outlined: first, that public associations must have full independence and autonomy; secondly - and as a consequence: they must receive the guarantee from the state regarding the inadmissible interference and obstruction of their activity. In the context of the above, it is important to introduce postulates similar to Europe not only at the legislative level, but within the scope of substantive implementation of such directives and provisions [6].

European and American democratic approach must be borrowed by Ukraine. The emphasis should be placed correctly: firstly, democracy is an instrument of the rule of people, and secondly, the rule of people is manifested in giving full freedom to citizens and legal entities that have the right to establish public organizations to express their civic and political position.

Non-government organizations always link the topic and purpose of their own activities with the receipt of social, not financial benefit. The experience of the European Union and the United States of America shows that freedom and democratism function simultaneously: economic, social and political well-being of the state is always equated with civic activities. Martin Luther King said, «Rebellion - is the language of those who have not 
been heard». Indeed, in order for there to be no precedent for public discontent, it must be heard: there must be a timely response to it. The government must respond to social discontent through dialogue with citizens, because the basis of true democracy is respect for the human essence and the will to choose. It is worth mentioning the words of Nelson Mandela, who noted that «to be free is not just to get rid of oppression; it means, first and foremost, respecting and increasing the freedom of others». This statement, although it has a more social, rather than political underlying idea, it demonstrates as follows: freedom - is a social phenomenon, because the sources of its formation are the concept of the common good, combined with respect and cultivation of understanding and awareness of human will, freedom and independence from external, political or social factors [7].

\section{References:}

1. Джон Райт: ЄС підтримує громадські організації, які мають чітке бачення змін [Електронний ресурс] // Громадська організачія «Інформаційно-аналітичний иентр «Громадський Простір» - Режим доступу до ресурсу: https://www.prostir.ua/?focus=es-pidtrymujehromadski-orhanizatsiji-yaki-mayut-chitke-bachennya-zmin.

2. Угода про асоціацію між Україною, з однієї сторони, та Європейським Союзом, Свропейським співтовариством з атомної енергії і їхніми державами-членами, з іншої сторони / Верховна Рада Украӥни [Електронний ресурс] - Режим доступу до ресурсу: https://zakon.rada.gov.ua/laws/show/984_011\#Text.

3. Крушельницька Т. П. Громадянське суспільство: проблеми і напрями інституційного розвитку / Т. П. Крушельницька, В. В. Карлова. Київ, 2008. - 56 с. - (НАДУ).

4. Енгибарян Р. В. Конституционное развитие в современном миpe. Основные тенденции / Р. В. Енгибарян. - Москва: Норма, 2007. $496 \mathrm{c}$.

5. Закон Украӥни «Про громадські об'єднання» : Документ 4572-VI / Відомості Верховної Ради України [Електронний ресурс] - Режим доступу до ресурсу: https://zakon.rada.gov.ua/laws/show/4572-17\#Text.

6. Бабкіна О. В. Політологія / О. В. Бабкіна, В. П. Горбатенко. Київ: Академія, 2006. - 568 с.

7. Кучик О. С. Міжнародні організаціі / О. С. Кучик. / Знання. 2007. - №2. - C. 749 c. 